\title{
THE USE OF ANALGESICS AMONG POZNAŃ MARATHON RUNNERS
}

original paper

( ) University School of Physical Education in Wroclaw

DOI: https://doi.org/10.5114/hm.2019.83993

\section{JOANNA KAMIŃSKA, MACIEJ PAWLAK}

Chair of Biomedical Foundations of Physical Activity, Department of Biochemistry,

Poznan University of Physical Education, Poznań, Poland

\section{ABSTRACT}

Purpose. Running is becoming an increasingly more popular form of leisure activity. However, intense physical activity, such as running a marathon, can put a significant strain on the body and lead to the use of painkillers to reduce or avoid pain. Therefore, the purpose of the research was to determine the percentage of participants in the Poznań Marathon taking analgesics before or during the run and to investigate the runners' knowledge about the possible negative health effects of such behaviour.

Methods. The study was carried out in 3 consecutive years (2014-2016) among 308 runners participating in the Poznań Marathon. The respondents completed a survey consisting of 3 parts: (1) personal details, (2) use of analgesics before and/ or during the marathon run, and (3) the runner's awareness of the possible negative effects of using such medicines during increased physical activity.

Results. Taking analgesics before or during a marathon run was declared by $18.6 \%, 14.9 \%$, and $16.8 \%$ of the participants in years 2014, 2015, and 2016, respectively. Compared with men, women used painkillers more frequently (22.3\% vs. $16.1 \%$ ). On average, $59.3 \%$ of runners believed that using analgesics might be harmful to their health and increase the risk of injury, but $39.8 \%$ of them took painkillers anyway.

Conclusions. Nearly every sixth participant of the Poznań Marathon used analgesics before or during running because of the pain they experienced or expected. The awareness of analgesic-related side effects did not stop the runners from using painkillers.

Key words: pain, injury, physical exercise, painkillers

\section{Introduction}

Physical activity is perceived as an important aspect of life, associated with various positive, proven health effects [1, 2]. However, excessive effort may disrupt the homeostasis of the human body [3] and, directly or indirectly, cause overload and/or injuries.

For the recent several years, growing interest in various forms of physical activity has been observed in Poland. One of the most popular forms of such activity, especially among amateurs, is long-distance running [3-5]. Indeed, the number of people competing in the Poznan Marathon has increased more than 7 times over the past 16 years [6].
In a long-distance race, the physical exertion of the locomotor system leads to a higher probability of damage to muscles, tendons, and bones [7-9], articular injury in the lower limb [4, 5], or musculoskeletal pain [10]. In turn, the incidence of injuries during long-distance runs was found to range from 3.2 to 59 per 1000 hours $[4,11,12]$ and $2-8 \%$ of marathon participants made use of medical assistance during the race or immediately after the competition [13, 14]. Both those injuries and indirect consequences of high musculoskeletal load lead to the occurrence of pain in runners, with varying location and type of affected tissue. Some runners, to reduce or eliminate pain, take analgesics before the start or during the marathon [15-18].

Correspondence address: Joanna Kamińska, Department of Biochemistry, Poznan University of Physical Education, ul. Królowej Jadwigi 27/39, 61-871 Poznań, Poland, e-mail: jkaminska@awf.poznan.pl

Received: June 19, 2018

Accepted for publication: December 27, 2018

Citation: Kamińska J, Pawlak M. The use of analgesics among Poznań Marathon runners. Hum Mov. 2019;20(3):23-28; doi: https://doi.org/10.5114/hm.2019.83993. 
J. Kamińska, M. Pawlak, The use of analgesics among Poznań Marathon runners

The use of analgesics, aside from the temporary pain relief, is associated with multiple severe side effects. None of the painkillers applied by runners is neutral to the gastric mucosa and the digestive tract [19]; they are also able to disturb the fluid and electrolyte balance [20-23] and reduce kidney function [24-26].

The increasing number of papers describing the consumption of analgesics among runners indicate a real worldwide problem, which is also present in Poland [17]. In order to obtain more information about this phenomenon in Poland, a 3-year study was carried out to explore the potential negative health effects of such behaviour and its variability over time.

\section{Material and methods}

The study material included an anonymous, voluntary survey filled in by a total of 308 runners who participated in the Poznań Marathon across 3 consecutive years: 2014 (82 runners: 58 men and 24 women), 2015 (107: 64 men and 43 women), and 2016 (119: 78 men and 41 women). This corresponded with $1.3 \%$, $1.7 \%$, and $2.0 \%$ of the runners who completed the marathon in the respective years.

The survey consisted of the same questions each year, with the exception of one introduced in the last 2 years, which intended to exclude runners who had taken part in this research previously, in 2014 and/or 2015. The first part of the survey included questions considering sex, age, weight, and body height, place of residence, and level of education, whereas the questions in the next section dealt with the use of analgesics immediately before and during long-distance running, the type of this medication, as well as the reason for its consumption. Moreover, the respondents were asked whether the use of analgesics before and during intensive exercise could have a negative effect on their health and, if so, which adverse effects they thought were possible. The questionnaire contained both open-ended and closed-ended questions and in some cases allowed multiple answers. The survey was conducted with the runners either personally or electronically, within 2 weeks after completing the marathon.

The surveyed indicators used in the study were presented as numbers (mean with standard deviation) and percentage rates. All tested variables were checked for normality of distribution with the Shapiro-Wilk test. In order to compare the results from the 3 analysed years, the Kruskal-Wallis ANOVA test and the Mann-Whitney $U$ test were applied to the quantitative variables and the $\chi^{2}$ test to qualitative variables; these were used to assess potential differences between the studied variables and to compare the differences between the sexes, respectively. All statistical analyses were performed with the use of the STATISTICA 12.0 computer statistical package (StatSoft, Inc., Tulsa, USA). Significant results were defined at $p<0.05$.

\section{Ethical approval}

The research related to human use has been complied with all the relevant national regulations and institutional policies, has followed the tenets of the Declaration of Helsinki, and has been approved by the Bioethical Committee of the Poznan University of Medical Sciences (approval No.: 714/14).

\section{Results}

The results of this study, which spanned 3 consecutive years, confirmed that painkillers were used by amateur marathon runners in Poland. The average age of the participants involved in the study was about 30 years and the percentage rate of subjects over the age of $40 \mathrm{did}$ not exceed 14.6\% (Table 1). None of the parameters evaluated in the study showed statistical differences in the consecutive years (Table 1).

We found that an affirmative answer to the question 'Did you take painkillers immediately before or during the marathon run?' was given, on average, by $16.8 \%$ of the respondents in each of the years; however, no statistically significant differences were observed (Figure 1).

When comparing the number of people taking analgesics directly before the run in the 3 analysed years, a statistically significant difference was noted only between the results for 2014 and 2015. However, where analgesics were used during the run, a statistically significant difference was found between all test dates (Table 2).

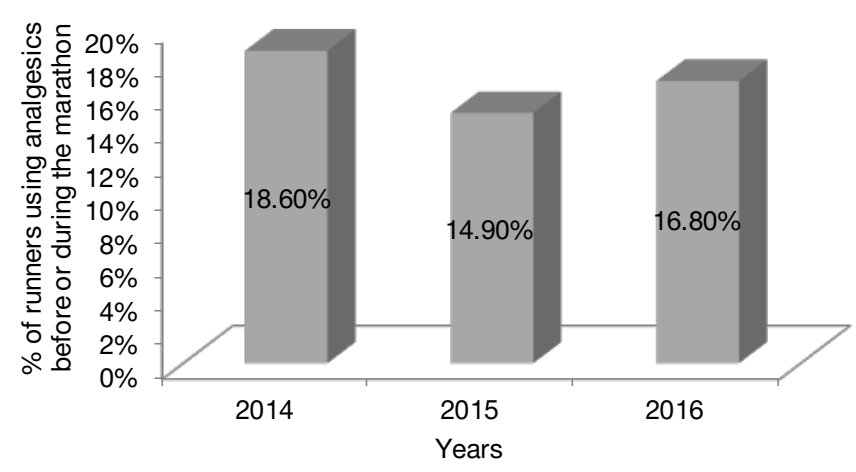

Figure 1. Percentage distribution of runners who used analgesics in subsequent years 
Table 1. Description of participants in the Poznań Marathon in 2014-2016

\begin{tabular}{|c|c|c|c|c|c|c|c|c|c|}
\hline \multirow{2}{*}{ స్ర } & \multirow{2}{*}{ Sex } & \multirow{2}{*}{$\begin{array}{l}\text { Age (years) } \\
(\text { mean } \pm S D)\end{array}$} & \multirow{2}{*}{$\begin{array}{l}\text { BMI }\left(\mathrm{kg} / \mathrm{m}^{2}\right) \\
(\text { mean } \pm S D)\end{array}$} & \multicolumn{3}{|c|}{ Place of residence $(\%)^{\mathrm{a}}$} & \multicolumn{3}{|c|}{ Level of education (\%) } \\
\hline & & & & Village & Small town & Large city & Primary & Secondary & Tertiary \\
\hline \multirow{3}{*}{$\stackrel{\text { H }}{\stackrel{i}{d}}$} & $\begin{array}{l}\text { Female } \\
(n=24)\end{array}$ & $30.1 \pm 8.1$ & $21.6 \pm 3.2$ & 12.5 & 16.7 & 70.8 & 0.0 & 29.2 & 70.8 \\
\hline & $\begin{array}{c}\text { Male } \\
(n=58)\end{array}$ & $32.8 \pm 8.1$ & $24.1 \pm 2.4$ & 8.6 & 19.0 & 72.4 & 1.7 & 17.2 & 81.1 \\
\hline & $\begin{array}{c}\text { Total } \\
(n=82)\end{array}$ & $32.0 \pm 8.1$ & $23.4 \pm 2.9$ & 9.8 & 18.3 & 71.9 & 1.2 & 20.7 & 78.1 \\
\hline \multirow{3}{*}{$\stackrel{10}{\stackrel{2}{N}}$} & $\begin{array}{l}\text { Female } \\
(n=43)\end{array}$ & $29.6 \pm 7.2$ & $21.1 \pm 1.2$ & 7.0 & 9.3 & 83.7 & 0.0 & 27.9 & 72.1 \\
\hline & $\begin{array}{c}\text { Male } \\
(n=64)\end{array}$ & $29.6 \pm 6.2$ & $23.1 \pm 1.5$ & 6.3 & 7.8 & 85.9 & 0.0 & 23.4 & 76.6 \\
\hline & $\begin{array}{c}\text { Total } \\
(n=107)\end{array}$ & $29.6 \pm 6.6$ & $22.3 \pm 1.4$ & 6.6 & 8.4 & 85.0 & 0.0 & 25.2 & 74.8 \\
\hline \multirow{3}{*}{ 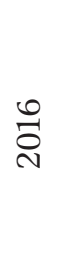 } & $\begin{array}{l}\text { Female } \\
(n=41)\end{array}$ & $29.2 \pm 6.8$ & $21.3 \pm 1.1$ & 12.2 & 4.9 & 82.9 & 0.0 & 39.0 & 61.0 \\
\hline & $\begin{array}{c}\text { Male } \\
(n=78)\end{array}$ & $32.4 \pm 7.6$ & $23.7 \pm 1.7$ & 2.6 & 8.9 & 88.5 & 0.0 & 21.8 & 78.2 \\
\hline & $\begin{array}{c}\text { Total } \\
(n=119)\end{array}$ & $31.3 \pm 7.3$ & $22.9 \pm 1.5$ & 5.9 & 7.5 & 86.6 & 0.0 & 27.7 & 72.3 \\
\hline
\end{tabular}

$S D$ - standard deviation, BMI - body mass index

a Village - less than 10,000 inhabitants, small town - from 10,000 to 100,000 inhabitants,

large city - over 100,000 inhabitants

Table 2. Comparison of available publications concerning the use of analgesic agents by runners

\begin{tabular}{|c|c|c|c|c|c|c|c|}
\hline \multirow[b]{3}{*}{ Author } & \multicolumn{7}{|c|}{ Competition } \\
\hline & \multirow[b]{2}{*}{ Type } & \multirow[b]{2}{*}{ Year } & \multirow[b]{2}{*}{ Place } & \multirow[b]{2}{*}{$\begin{array}{l}\text { Number of } \\
\text { participants }\end{array}$} & \multicolumn{3}{|c|}{ Analgesics used } \\
\hline & & & & & $\begin{array}{l}\text { Within } 24 \mathrm{~h} \\
\text { before the run } \\
(\%)\end{array}$ & $\begin{array}{l}\text { Immediately } \\
\text { before the run } \\
(\%)\end{array}$ & $\begin{array}{c}\text { During } \\
\text { the run } \\
(\%)\end{array}$ \\
\hline \multirow{3}{*}{ Own research } & & 2014 & & 82 runners & - & 13.4 & 8.5 \\
\hline & Marathon & 2015 & Poznań (Poland) & 107 runners & - & 14.9 & 0.9 \\
\hline & & 2016 & & 119 runners & - & 14.2 & 4.3 \\
\hline Brune et al. [15] & Marathon & 2009 & Bonn (Germany) & - & \multicolumn{2}{|c|}{61.5} & - \\
\hline Küster et al. [16] & Marathon & 2010 & Bonn (Germany) & 3913 runners & - & 49.3 & - \\
\hline Reid et al. [20] & Marathon & 2002 & $\begin{array}{l}\text { Christchurch } \\
\text { (New Zealand) }\end{array}$ & 134 runners & 13.4 & - & - \\
\hline Almond et al. [21] & Marathon & 2002 & Boston (USA) & 488 runners & \multicolumn{2}{|c|}{55.5} & - \\
\hline Wharam et al. [22] & $\begin{array}{l}\text { Ironman } \\
\text { triathlon }\end{array}$ & 2004 & New Zealand & 330 athletes & \multicolumn{3}{|c|}{30.0} \\
\hline Brune et al. [26] & Marathon & 2007 & Switzerland & - & \multicolumn{2}{|c|}{30.0} & - \\
\hline Nieman et al. [27] & Ultramarathon & 2004 & California (USA) & 60 runners & - & - & 72.0 \\
\hline Gorski et al. [28] & $\begin{array}{l}\text { Ironman } \\
\text { triathlon }\end{array}$ & 2008 & $\begin{array}{l}\text { Florianópolis } \\
\text { (Brazil) }\end{array}$ & 1250 athletes & 25.5 & 17.9 & 47.4 \\
\hline
\end{tabular}




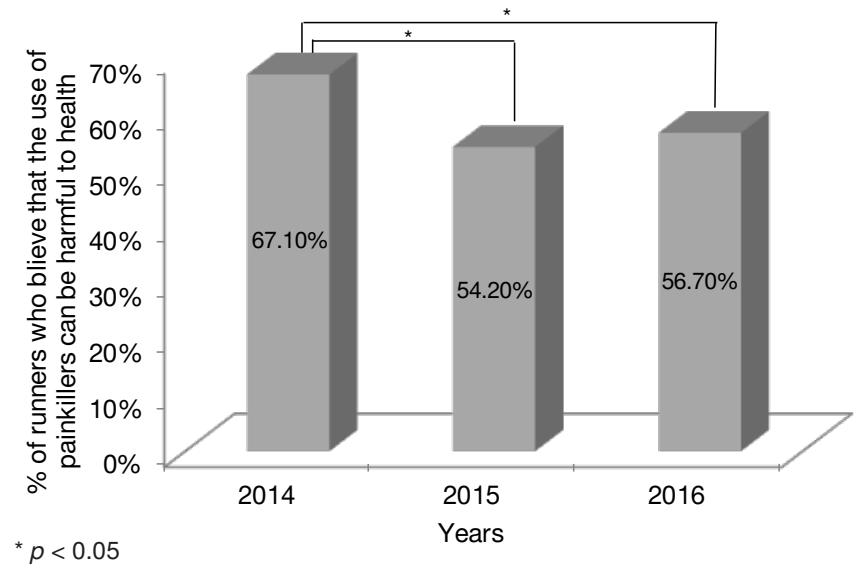

Figure 2. Percentage distribution of runners in the 3 consecutive years who supposed that using analgesics could be harmful to health

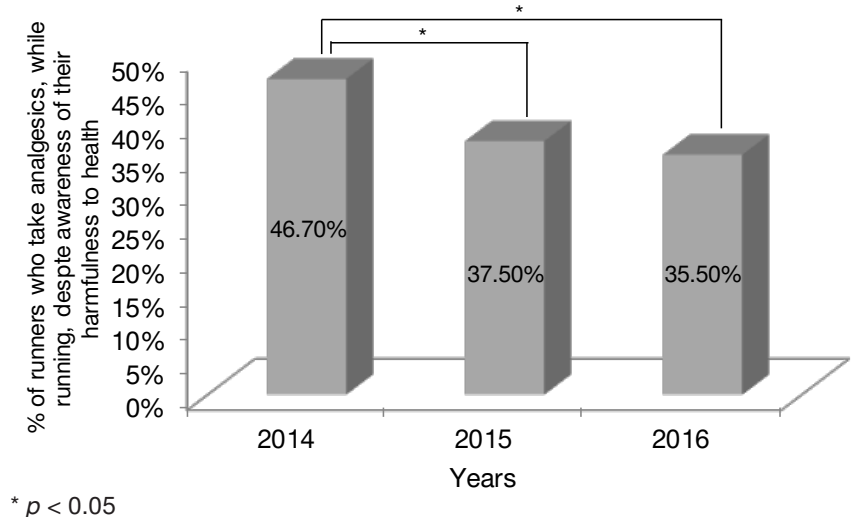

Figure 3. Percentage distribution of runners who use analgesics while running despite knowing their harmfulness to health. The result for 2014 is significantly higher than the results for the remaining years

With regard to the willingness to use painkillers, no statistically significant differences were revealed between men and women in years 2014-2016; however, the percentage of women (on average $22.3 \%$ ) who took such drugs was higher compared with men (on average $16.1 \%$ ). Interestingly, there were no statistically significant differences in the taking of analgesics or in the reasons for their use in relation to the runners' sex, place of residence, or level of education.

The runners most often used drugs containing predominantly ibuprofen, followed by ketoprofen, paracetamol, drotaverine, and diclofenac.

When asked about the reasons for taking analgesics, the marathon runners argued that they experienced pain or, in 3 cases in 2014, 2 in 2015, and 5 in 2016, they perceived the medicine application as a preventive means to avoid or reduce pain during the run.

To assess whether the runners were aware of the consequences of using the painkillers shortly before or during intense exercise, the respondents were asked to answer the question: 'Do you think that painkillers used before or during increased physical activity can give rise to negative health effects?' On average, 59.3\% of them gave affirmative responses, characterised by statistically significant differences in the analysed years (Figure 2).

The answer to the next question of the survey: 'Do you understand the potential danger of taking analgesics?' given by the runners who used them was interesting. They were aware that the use of analgesics could cause different kinds of adverse physiological effects (43.6\% in 2014, $86.2 \%$ in $2015,78.5 \%$ in 2016 ) and lead to an increase in injuries through pain relief (38.2\% in 2014, $55.2 \%$ in 2015, $35.9 \%$ in 2016).

The results of the study clearly indicate that the awareness of the harmfulness of-taking analgesics before or during intense physical exercise is not a sufficient factor to deter runners from using painkillers. Nearly $40 \%$ of the runners (39.8\%) who declared to use analgesics believed in their hazardous nature. Despite this knowledge, they decided to consume them. The specific percentages of respondents in each of the years is presented in Figure 3.

\section{Discussion}

The participants of our study were $30.6 \pm 7.4$ years old and the mean age did not differ statistically between both sexes. Other studies described mainly subjects who were, on average, 10 years older [16, 21, 27].

A comparison of data on the use of analgesics during marathon runs is shown in Table 2.

The use of painkillers, both in the authors' own research and in other publications [16, 20, 28], was motivated by the runners' desire to remove or avoid pain while running. Our data, including a clear conclusion that more women than men took painkillers, are consistent with the results found for the marathons in Bonn [16] and in Boston [21]. The percentage of women using analgesics was $19 \%$ and $8 \%$ higher than the percentage of men who did so in those 2 marathon locations, respectively.

Furthermore, the spectrum of painkillers, including ibuprofen, ketoprofen, diclofenac, or paracetamol used by the Poznan runners did not differ from the profile of analgesic drugs taken by long-distance athletes running in other countries [16, 27].

The vast majority of competitors in the Poznań Marathon (on average 59\%) were aware that the use of analgesics before or during increased intensity exercise might induce negative health effects. Most par- 
ticipants taking part in the marathon in Bonn 8 years before lacked such knowledge. At that time, about 93\% of the competitors declared not to be informed about the possible health risks associated with the use of analgesics during exercise [16].

The marathon runners in Poznań were conscious that the possible negative health effects of using analgesics during a run included problems with the digestive tract, the kidneys, and the liver, as well as a greater possibility of injuries. The participants of the triathlon in Brazil mainly pointed to gastrointestinal and kidney problems [28].

Among the Poznań Marathon runners declaring the use of analgesics, an average of $39.8 \%$ decided to consume them despite being convinced of the dangers of their use. In related publications, no such information was provided.

This study confirms that marathon runners have applied analgesics before or during running a marathon for decades. The awareness of analgesic-related side effects did not stop them from using painkillers.

Bearing in mind the many negative effects associated with the use of painkillers by participants of major running events, such as marathons, and the scale of the phenomenon described in this paper, we suggest to start an information campaign targeting the dangers of using such remedies, especially by high-performance athletes [25] or even non-athletes and healthy children [29].

\section{Conclusions}

Nearly every $6^{\text {th }}$ participant of the Poznan Marathon used analgesics before running (on average 84\%) and/or during running (on average 27\%) because of the experienced or expected pain. The awareness of analgesic-related side effects did not deter runners from using painkillers.

Although more than half of the respondents in the surveyed groups believed that the use of analgesics before or during physical activity might have negative health effects, it is advisable to implement a programme to raise the awareness of the risks associated with the use of painkillers, especially non-steroidal anti-inflammatory drugs.

\section{Disclosure statement}

No author has any financial interest or received any financial benefit from this research.

\section{Conflict of interest}

The authors state no conflict of interest.

\section{References}

1. Hur S, Kim SR. The effects of exercise therapy on CVD risk factors in women. J Phys Ther Sci. 2014;26(9): 1367-1370; doi: 10.1589/jpts.26.1367.

2. Sabourin BC, Stewart SH, Watt MC, Krigolson OE. Running as interoceptive exposure for decreasing anxiety sensitivity: replication and extension. Cogn Behav Ther. 2015;44(4):264-274; doi: 10.1080/16506073.2015. 1015163.

3. Tschopp M, Brunner F. Diseases and overuse injuries of the lower extremities in long distance runners [in German]. Z Rheumatol. 2017;76(5):443-450; doi: 10.1007/s00393-017-0276-6.

4. Van Gent RN, Siem D, van Middelkoop M, van Os AG, Bierma-Zeinstra SMA, Koes BW. Incidence and determinants of lower extremity running injuries in long distance runners: a systematic review. Br J Sports Med. 2007;41(8):469-480; doi: 10.1136/bjsm.2006.033548.

5. Van Poppel D, Scholten-Peeters GG, van Middelkoop M, Verhagen AP. Prevalence, incidence and course of lower extremity injuries in runners during a 12-month follow-up period. Scand J Med Sci Sports. 2014;24(6): 943-949; doi: 10.1111/sms.12110.

6. Poznań Maraton. Available from: http://marathon. poznan.pl/strefa-zawodnika/statystyki/.

7. Taunton JE, Ryan MB, Clement DB, McKenzie DC, Lloyd-Smith DR, Zumbo BD. A retrospective case-control analysis of 2002 running injuries. Br J Sports Med. 2002;36(2):95-101; doi: 10.1136/bjsm.36.2.95.

8. Clarkson PM, Hubal MJ. Exercise-induced muscle damage in humans. Am J Phys Med Rehabil. 2002; 81(11 Suppl):S52-S69; doi: 10.1097/01.PHM.00000 29772.45258.43.

9. Héroux ME, Gandevia SC. Human muscle fatigue, eccentric damage and coherence in the EMG. Acta Physiol. 2013;208(4):294-295; doi: 10.1111/apha.12133.

10. Teixeira RN, Lunardi A, da Silva RA, Lopes AD, Carvalho $\mathrm{CRF}$. Prevalence of musculoskeletal pain in marathon runners who compete at the elite level. Int J Sports Phys Ther. 2016;11(1):126-131.

11. Van Middelkoop M, Kolkman J, Van Ochten J, Bierma-Zeinstra SMA, Koes B. Prevalence and incidence of lower extremity injuries in male marathon runners. Scand J Med Sci Sports. 2008;18(2):140-144; doi: 10.1111/j.1600-0838.2007.00683.x.

12. Saragiotto BT, Yamato TP, Hespanhol Junior LC, Rainbow MJ, Davis IS, Lopes AD. What are the main risk factors for running-related injuries? Sports Med. 2014;44(8):1153-1163; doi: 10.1007/s40279-014-0194-6.

13. Crouse B, Beattie K. Marathon medical services: strategies to reduce runner morbidity. Med Sci Sports Exerc. 1996;28(9):1093-1096; doi: 10.1097/00005768-19960 9000-00003.

14. Roberts WO. A 12-yr profile of medical injury and illness for the Twin Cities Marathon. Med Sci Sports Exerc. 2000;32(9):1549-1555; doi: 10.1097/00005768-20000 9000-00004. 


\section{HUMAN MOVEMENT}

J. Kamińska, M. Pawlak, The use of analgesics among Poznań Marathon runners

15. Brune K, Niederweis U, Kaufmann A, Küster-Kaufmann M. Drug use in participants of the Bonn Marthon 2009 [in German]. MMW Fortschr Med. 2009;151(40): 39-41.

16. Küster M, Renner B, Oppel P, Niederweis U, Brune K. Consumption of analgesics before a marathon and the incidence of cardiovascular, gastrointestinal and renal problems: a cohort study. BMJ Open. 2013;3(4): e002090; doi: 10.1136/bmjopen-2012-002090.

17. Kamińska J, Pawlak M. Consumption of analgesics among runners of the Poznań Marathon. Trends Sport Sci. 2015;1(22):33-37.

18. Prior MJ, Lavins BJ, Cooper K. A randomized, placebo-controlled trial of acetaminophen extended release for treatment of post-marathon muscle soreness. Clin J Pain. 2012;28(3):204-210; doi: 10.1097/AJP.0b013e 318227cc4f.

19. Halvorsen FA, Lyng J, Ritland S. Gastrointestinal bleeding in marathon runners. Scand J Gastroenterol. 1986;21(4):493-497;doi:10.3109/00365528609015168.

20. Reid SA, Speedy DB, Thompson JM, Noakes TD, Mulligan G, Page T, et al. Study of hematological and biochemical parameters in runners completing a standard marathon. Clin J Sport Med. 2004;14(6):344-353; doi: 10.1097/00042752-200411000-00004.

21. Almond CS, Shin AY, Fortescue EB, Mannix RC, Wypij D, Binstadt BA, et al. Hyponatremia among runners in the Boston Marathon. N Engl J Med. 2005; 352(15):1550-1556; doi: 10.1056/NEJMoa043901.

22. Wharam PC, Speedy DB, Noakes TD, Thompson JM, Reid SA, Holtzhausen LM. NSAID use increases the risk of developing hyponatremia during an Ironman triathlon. Med Sci Sports Exerc. 2006;38(4):618-622; doi: 10.1249/01.mss.0000210209.40694.09.

23. Tscholl P, Alonso JM, Dollé G, Junge A, Dvorak J. The use of drugs and nutritional supplements in top-level track and field athletes. Am J Sports Med. 2010;38(1): 133-140; doi: 10.1177/0363546509344071.

24. Farquhar B, Kenney LW. Anti-inflammatory drugs, kidney function, and exercise. Sports Sci Exchange. 1997;11(4):1-5.

25. Clarkson PM. Exertional rhabdomyolysis and acute renal failure in marathon runners. Sports Med. 2007; 37(4-5):361-363; doi: 10.2165/00007256-20073704000022.

26. Brune K, Niederweis U, Krämer BK. Sports and painkillers: unholy alliance to the damage of the kidney [in German]. Dtsch Arztebl. 2008;105(37):1894-1897.

27. Nieman DC, Dumke CL, Henson DA, McAnulty SR, Gross SJ, Lind RH. Muscle damage is linked to cytokine changes following a $160-\mathrm{km}$ race. Brain Behav Immun. 2005;19(5):398-403; doi: 10.1016/j.bbi.2005.03.008.

28. Gorski T, Cadore EL, Pinto SS, da Silva EM, Correa CS, Beltrami FG, et al. Use of NSAIDs in triathletes: prevalence, level of awareness and reasons for use. Br J Sports Med.2011;45(2):85-90;doi:10.1136/bjsm.2009.062166.
29. Krause I, Cleper R, Eisenstein B, Davidovits M. Acute renal failure, associated with non-steroidal anti-inflammatory drugs in healthy children. Pediatr Nephrol. 2005;20(9):1295-1298; doi: 10.1007/s00467-0051966-x. 